\title{
The Consequences of Partisanship in Africa
}

\section{Robert Mattes and Matthias Krönke}

Since its development by Angus Campbell and his colleagues (1960), the concept of partisan identification has been the subject of a number of important debates. Some scholars have questioned whether it really exists independently of voting preferences, especially outside of the United States (Gunther, Montero, \& Puhle, 2006). Others have questioned whether partisanship is only a result of "long term" structural and demographic forces (as posited by Campbell et al.), or responds to more "medium term" factors relating to citizens' evolving perceptions of the attributes and performance of alternative political parties (Key, 1967; Fiorina, 1981).

For many years following publication of The American Voter, scholars of African electoral politics simply ignored the concept. Much of this stemmed from the lack of micro level survey data, forcing analysts to draw inferences from macro level associations of region or district and aggregate voting patterns (Burnell, 2002; Christopher, 1996; Ojo, 1981; Reynolds, 1994; Smith, 2002; Takougang, 1996). Yet much of it was also the function of the widespread acceptance of sociological accounts of individual behaviour emphasizing the role of interpersonal and group influence. Indeed, some survey-based analyses of African voters still fail to measure the concept or include the variable (e.g., Badedau et al., 2011; Ishiyama, 2012; Lindberg, 2003; Lindberg \& Morrison, 2008).

Scholars of Africa have traditionally seen ethnicity - based on kinship and family; language and dialect; and region - as the prime social and political identity, shaping both attitudes and behaviours (Basedau et al., 2010; Daddieh \& Fair, 2002; Horowitz, 1985; Hyden, 2013; Rabushka \& Shepsle, 1972; Palmberg, 1999; Young, 1976). Given low levels of occupational stratification, education, or access to news media, votes cast in multi-party elections are understood either as affective expressions of social identity, or as instrumental bets using ethnicity as a low information cue as to which candidate or party is most likely to represent their interests.

At least in the field of electoral politics, however, scholars have begun to question the extent and degree to which ethnicity influences how Africans vote (Bratton, Bhavnani \& Chen, 2012; Bratton \& Kimenyi, 2008; Ferree, 2011; Mattes, 1995; Mattes \& Gouws, 1997; Mattes \& Piombo, 2001; Norris \& Mattes, 2003). One key line of attack is premised on the fact that, even if ethnicity was the key determinant of political behaviour, many countries have far more ethnic groups than political parties (e.g., Ghana). Thus, many voters do not 
have a direct ethnic stake in national presidential contests. How do these voters, especially those with little access to independent news media, connect their own identity to that of competing candidates or parties? Moreover, strategically minded parties recruit legislative and other lower-level candidates who share voter identities, even if that party is historically associated with some other region, or other group. In this case, the vote has less clear implication for group interests. A final line of attack argues that Africans' daily experiences provide voters with sufficient information about economic trends and the delivery of local public goods, over and above the ethnic identify of candidates and parties, which they can use to make more sophisticated choices.

Given this background, we first examine the degree to which partisan identification exists in Africa. Second, we test whether partisanship helps people organize their political world. Does it shape the extent to which people vote, or engage in politics during and between elections? And do specific partisan identifies shape the way people vote? Finally, we conclude with an exploration of the nature of the effect of partisanship in Africa. Is it a relatively fixed, enduring function of ethnic identity that serves to divide people into different, permanent "political tribes"? Or does it function mainly as a political "schema," or cognitive lens, that helps them process political information, but which may also change over time in accordance with national economic trends and political events? Ironically, answering such a question is not only important for the study of democracy and elections in Africa, but is becoming increasingly relevant for western societies, such as the United States, where Democrats and Republicans are now regularly referred to as "political tribes".

We use two main data sets. First, to obtain estimates for the widest array of African countries, we use data from Round 6 of the Afrobarometer, which conducted surveys in 36 countries in 2015-2016. Second, to examine overtime change, we use a set of 20 countries that have been surveyed by Afrobarometer since at least 2005 .

\section{Partisan Identification in Africa}

Departing from at least two different theoretical starting points, one might not expect to find very high levels of partisanship in Africa. On one hand, from an extreme ethnicist position, in a world where political attitudes and behaviours are determined by ethnic identities, voters would not require a distinct and meaningful partisan identify. Rather, they could simply rely on ethnic cues to tell them how to vote when they enter the polling station. On the other hand, from a rational choice position, in a world where political parties are widely seen to be ephemeral, personal vehicles that rarely adopt sets of policy stances which differ from other 
parties (Englebert \& Dunn, 2014), voters would have little reason to identify with any party, and rather remain unaffiliated.

In contrast to both expectations, post-election surveys in South Africa (Mattes, Gouws $\&$ Kotze, 1995), and early Afrobarometer surveys of 12 largely Anglophone, southern Africa countries (Bratton, Mattes, \& Gyimah-Boadi, 2005), have found significant, though not overwhelming levels of partisanship. In the most recent available cross-national data, based on surveys of nationally representative samples of 52,735 respondent in 35 countries conducted in 2015-2016, 56 per cent answered in the affirmative when asked: "Do you feel close to any particular political party?." ${ }^{1}$ Yet this cross-national average actually describes relatively few countries as the proportions vary widely around the Afrobarometer mean (see Figure 1). About three-in-four respondents identify with a political party in Niger, Namibia, Tanzania, Malawi, Sierra Leone, Uganda, and South Africa. At the other end of the continuum, just one-in-four people do so in Egypt and Mauritius.

One thing that immediately stands out is the apparent impact of colonial legacies. Only three non-former British colonies (Niger, Burundi, and Senegal) place in the top half of the series. And Zambia and Mauritius are the only former British colonies in the bottom half. This is most probably a reflection of the electoral system selected in the post-independence period. Almost all former British systems use plurality voting rules to choose legislators in single member districts (even though almost all changed from parliamentary to presidential executives in the post-independent period); and every former French or Portuguese system uses a system that employs at least some form of proportional rules to choose legislators in multi-member districts (Go, 2002). Most former French systems also adopted the two-round system of the French $5^{\text {th }}$ Republic to elect the President. When combined with proportional representation for legislative races, this has the effect of encouraging the combination of multiple parties and grand coalitions. Yet legacies can also endure system changes: for instance, as a former British colony, South Africa exhibits high levels of partisanship even though it changed its electoral system in 1994 to proportional representation with large regional and national districts.

[Figure 1 about here]

After the initial lead-in question, Afrobarometer then asks those respondents who say that they feel close to a party: "Which party is that?" The scholarly story of African political parties tends to revolve around ruling parties, driven largely by assumptions of dominant 
ruling parties and small, personalist, ephemeral opposition parties (e.g., Van de Walle \& Butler, 2007). In Figure 2, we see that the ruling party, indeed, enjoys lopsided advantages in terms of voter identification in places like Namibia, Uganda, Tanzania, and Burundi. Yet at least one-in-three voters say they feel close to an opposition party in Liberia, Madagascar, Malawi, Lesotho, Kenya, Sierra Leone, Nigeria, Cote d'Ivoire, and Niger.

But the data also reveal a prime challenge which confronts the cause of opposition politics in Africa. First, support is usually spread across multiple opposition parties. Second, support is also spread across many opposition parties whose individual support bases are so small that they are not likely to be politically viable, at least in terms of national politics. We have segmented the proportions who feel close to an opposition party according to whether that party wins more, or less than 5 per cent of the national vote. Support for "non-viable" parties is substantial in countries such as Madagascar, Cote d'Ivoire, Liberia, and Burkina Faso.

[Figure 2 about here]

\section{What Does Partisanship Do?}

Now that we know something about the cross-national distribution of partisanship, and party identification in Africa, we turn our attention to its political consequences for political behaviour. Using the framework first developed by Verba and Nie (1972), we examine the effect of partisanship on voting, campaigning, communing, contacting and protesting. In terms of voting and campaigning, we find that partisans (72 per cent) are more likely than non-partisans (58 per cent) to report having voted in the previous national election. Partisans are also much more likely to report having attended a campaign rally (45 to 26 per cent), or campaign meeting (36 to 19 per cent). And they are twice as likely as non-partisans to report having persuaded other people how to vote (32 to 15 per cent), or having worked for a party or candidate (22 to 9 per cent).

But what about those who identify with opposition parties? Africa's opposition parties face a number of challenges in terms of funding and access to state news media, and are often seen as ephemeral vehicles for disgruntled individuals who have left the governing coalition. Thus, in Figure A1 in the Online Appendix, we disaggregate the partisans to test for systematic differences in the behavioural impact of ruling party and opposition party partisanship. However, they are minimal at best. Since Africa's opposition parties confront a host of challenges in terms of funding, organizational infrastructure, and access to state news 
media, this suggests that the impact of partisanship on behaviour is less one of organizational mobilization, but rather one of cognitive mobilization (Dalton, 1984).

But the behavioural effect of partisanship is not restricted to periodic election campaigns. Africa's partisans are also more likely to remain politically involved between elections. They are more prone to attend community meetings (59 to 43 per cent), join with others to raise political issues ( 49 to 38 per cent), and be leaders or active members of civic associations (26 to 18 per cent), than non-partisans. And while it might be expected that partisans are more likely to contact a party official between elections (21 to 9 per cent), they are also more likely to contact elected representatives such as local councillors (28 to 17 per cent), and MPs (15 to 7 per cent), as well as government officials (17 to 10 per cent). Finally, there is a small, though statistically significant difference between the propensity of partisans and non-partisans to report having joined a political protest (11 to 8 per cent). Again, besides attending community meetings, there are minimal differences between government and opposition supporters (Figure A2 in the Online Appendix).

The most important political consequence of partisanship, according to Campbell et al. (1960) is its ability to reduce complexity and provide a ready guide to voting decisions, especially where voters are confronted with longs lists of voting choices. But depending on the "short term" forces of a particular election campaign, emerging salient issues or attractive candidates might lead some voters to "defect" from their party identification and vote for a different candidate or party. In Africa, where voters are rarely presented with more than a few electoral choices in any given election, the data demonstrate that partisans are very likely to vote for the specific party with which they identify (see Table 1). Almost nine-in-ten respondents who identify with a ruling party say they would vote for a candidate from their party "if presidential elections were held tomorrow," while one-in-twenty say they would defect and vote for a candidate from another party. Opposition identifiers are slightly less likely to remain loyal (84 per cent) and one-in-ten say they would defect and vote for another party. In contrast, 25 per cent of non-partisans say they would vote for the ruling party, 55 per cent say they would vote for an opposition party, and 20 per cent say they would not vote.

This high conversion rate of party identification-to-vote is a testament to the power of partisanship, but also to the fact that respondents were asked only about their presidential vote. We might well find higher levels of defection if they had been asked about additional voting preferences for the legislature or other offices at different levels of government. Indeed, in South Africa where voters are presented with separate ballots for national and provincial legislative assemblies, 9 per cent of partisans reported to South African National 
Election Study interviewers that they defected at the national level in that country's 2014 election, and 11 per cent defected at the provincial level.

Table 1: Partisan Identification and Vote Choice (Per Cent)

\begin{tabular}{lcc} 
& $\begin{array}{c}\text { Identifies with } \\
\text { Governing Party }\end{array}$ & $\begin{array}{c}\text { Identifies with } \\
\text { Opposition Party }\end{array}$ \\
\hline Vote Loyalist & 88 & 84 \\
Vote Defector & 4 & 9 \\
Would Not Vote / & 5 & 5 \\
Don't Know & & \\
Won't Say & 3 & 2 \\
\hline Sum Per Cent & 100 & 100
\end{tabular}

Source: Afrobarometer Round 6 (2014-2015).

\section{Sources of Partisanship in Africa}

We began this analysis by positing an extreme hypothesis: if ethnic identities are so important in African politics, people would have little need for a separate partisan identity. However, a less extreme position might argue that while many Africans possess a distinct partisan identity, it simply is a reflection of their ethnic identity. While this chapter is not the place for a full test of the complex links between partisanship and ethnicity (measured in its multiple manifestations), or any other demographic or structural variable, we can gain some important purchase on this question by examining the association between the largest ethnic group and identification with governing and opposition parties. If African elections are ethnic censes (Horowitz, 1985), governing parties (by virtue of the fact that they are largest party) should tend to dominate amongst this group.

Thus, in Table 2, we rank each country included in the Afrobarometer by the size of the largest language group in the sample, and then examine the extent to which that group awards its support to the ruling party or to an opposition party. Three conclusion emerge. First, across all 33 countries, only around one-third of those who belong to the largest language group identity with the governing party. There are only six cases (out of 33) where a majority of the largest group identifies with the ruling party: the Kirundi (Burundi), Hasoussa (Niger), Makua (Mozambique), Zulu (South Africa), Kisukuma (Tanzania), and Dioula (Cote d'Ivoire). Second, while we might expect this to hinge on the relative size of the dominant group, we see no obvious relationship. In some cases where the dominant group offers low levels of support for the governing party, particularly when the largest group constitutes less than a majority of the total population, that group throws its support to an opposition party 
(e.g., the Mende in Sierra Leone, the Hausa in Nigeria, the Kikuyu in Kenya, or the Bassa in Liberia). But this comprises less than half of such cases.

Table 2. Co-Ethnicity and Identification with Governing Parties 2014/2015 (Per Cent)

Per Cent of Group

Per Cent of Group who Identify

Per cent of Who Identify with with Opposition

\begin{tabular}{|c|c|c|c|c|}
\hline Country & Language Group & Total sSample & Ruling Party & Parties \\
\hline \multicolumn{5}{|c|}{ Linguistically Homogenous } \\
\hline Cape Verde & Crioulo & 100 & 19 & 16 \\
\hline Tunisia & Arabic & 100 & 17 & 12 \\
\hline Sudan & Sudanese Arabic & 99 & 24 & 4 \\
\hline Lesotho & Sesotho & 99 & 21 & 41 \\
\hline Burundi & Kirundi & 99 & 58 & 12 \\
\hline Mauritius & Creole & 98 & 12 & 17 \\
\hline \multicolumn{5}{|c|}{ Predominant Language Group } \\
\hline Algeria & Algerian Arabic & 93 & 17 & 14 \\
\hline Sao Tome \& Principe & Portuguese & 90 & 34 & 19 \\
\hline Morocco & Arabic & 83 & 18 & 19 \\
\hline Botswana & Setswana & 77 & 44 & 26 \\
\hline Madagascar & Malgache & 64 & 3 & 42 \\
\hline Niger & Haoussa & 64 & 50 & 22 \\
\hline Senegal & Wolof & 63 & 26 & 27 \\
\hline Mali & Bambara & 55 & 34 & 30 \\
\hline Burkina Faso & Mooré & 55 & 8 & 20 \\
\hline Malawi & Chichewa & 51 & 22 & 48 \\
\hline Ghana & Akan & 50 & 10 & 45 \\
\hline \multicolumn{5}{|c|}{ Plurality Language Group } \\
\hline Zimbabwe & Shona & 48 & 45 & 16 \\
\hline Namibia & Oshiwambo & 46 & 71 & 6 \\
\hline Benin & Fon & 43 & 14 & 19 \\
\hline Guinea & Poular & 35 & 13 & 40 \\
\hline Togo & Ewe & 35 & 16 & 11 \\
\hline Sierra Leone & Mende & 31 & 6 & 56 \\
\hline Zambia & Bemba & 28 & 41 & 11 \\
\hline Mozambique & Makua & 27 & 63 & 9 \\
\hline Nigeria & Hausa & 26 & 15 & 66 \\
\hline Gabon & Fang & 25 & 18 & 17 \\
\hline South Africa & Zulu & 24 & 60 & 16 \\
\hline Uganda & Luganda & 21 & 38 & 25 \\
\hline Kenya & Kikuyu & 20 & 1 & 62 \\
\hline Tanzania & Kisukuma & 17 & 59 & 16 \\
\hline Cote d'Ivoire & Dioula & 17 & 63 & 5 \\
\hline Cameroon & French & 16 & 48 & 8 \\
\hline Liberia & Bassa & 10 & 10 & 58 \\
\hline$\overline{\text { Average }}$ & & 55 & 29 & 20 \\
\hline
\end{tabular}

Source: Afrobarometer Round 6 (2014-2015) for 35 African countries. 
So, if ethnicity only imperfectly correlates with party identification, could partisanship in Africa be better characterized in V.O. Key's (1967) term as a "standing choice" which, while initially shaped by background factors of family, class and community, can change over time if people's perceptions of national economic and political fortunes, and the government's responsibility for those trends, also change? As a first step, we point to an initial test carried out by Norris and Mattes (2003) on respondents from 12, mostly Anglophone and southern African countries surveyed in the first round of Afrobarometer, from 1999 to 2001. They found that while ethnicity is a statistically significant predictor of party identification, the size of its impact not only varies across countries, but that it is modest compared to the impact of evaluations of policy performance of the party in government.

We replicate this model with the data from the Afrobarometer Round 6 surveys reviewed in this chapter. This not only provides us with more up-to-date estimates, but also provides us with a range of countries representing all African regions, and a much greater variation in colonial background, electoral system and level of development (see Table A1 in the Online Appendix). We exclude the six countries where respondents belonging to the largest language group comprise 98 per cent of the sample or more. In the remaining 27 countries, we use logistic multiple regression with identification with the ruling party as the dependent variable. The first model examines the direct effects of belonging to the largest ethno-linguistic group. The second model adds controls for social characteristics widely used in studies of partisanship, including age, gender, urbanization, social class and education. The final model then examines the impact of what we call "medium term" factors (as opposed to the "long term" factors of demography and socialization, or the "short term" factors associated with election campaigns and specific candidates). These include respondents' evaluations of the overall direction of the country, national economic trends, and government "handling" of a range of macro-economic areas (managing the economy, controlling prices, creating jobs, controlling inequality, maintaining the living standards of the poor, and making sure people have enough to eat), and crime and corruption. ${ }^{2}$

Our findings largely echo the earlier conclusions drawn by Norris and Mattes (2003). First, ethnicity does matter. Members of the largest ethno-linguistic group are, on average across 27 countries, more likely to identify with the ruling party than other respondents, even after taking other structural and demographic issues into account, or their economic and political evaluations. Yet several other structural factors also matter: women, urban and older respondents are also more likely to support the ruling party, while those who work in a middle class occupation are less likely. The overall impact of both ethnicity and other 
structural factors, however, is quite limited. The model attains much greater explanatory power once we include whether people think the country is going in right direction, have optimistic views of national economic trends, and give the ruling party positive marks for their management of macro economic affairs, and crime and corruption. Thus, while ethnicity continues to play a limited role in structuring partisan identification, many voters seem to adjust their partisan identification (at least with regard to the ruling party) based on their views of the government's economic and political performance.

Yet because these results are based on cross-national data, we should not get too far ahead of ourselves. Indeed, critics might maintain that at best, the association between partisanship and performance evaluations is at best reciprocal, with evaluations and partisanship mutually influencing one another. At worst, they might argue that the apparent impact is simply a case of reverse causation: respondents know which party they support (due to ethno-regional loyalties), and then provide interviewers with appropriately biased reports of government performance depending on whether they support a ruling or an opposition party.

To assess both possibilities, we examine longitudinal trends, first, in partisan differences in performance evaluations, and second, in voter identification with Africa's governing parties. First, as illustrated in Figure A3 in the Online Appendix (using data from Uganda), partisanship clearly shapes how voters perceive economic and political reality. Ruling party identifiers have more optimistic views than opposition party supporters, with non-partisans somewhere in the middle. Thus partisan identities function as a cognitive lens that refract voters' perceptions of economic and political events and trends. This does not mean, however, that respondents' evaluations are hopelessly contaminated by partisanship. If members of these groups' views were purely a function of partisan identities, their ratings should remain unchanged, and the aggregate trend lines should remain flat. In fact, however, while their relative rankings remain the same, absolute evaluations change over time, as the economy changes.

And ifsurvey-based evaluations of ruling party performance are solely or largely determined by either partisan and ethnic identities, we should expect trends in aggregate levels of identification with a given ruling party to resemble a flat line, with over-time shifts caused only by generational or demographic change. However, as we can see in Figures A4 and A5 in the Online Appendix, trends in identification with African ruling parties exhibit considerable over-time variation. Even in the one-party dominant systems in our sample, where former liberation movements have consistently won national elections by large 
margins since the (re)introduction of multi-party competition, support for the ruling party appears to be in various stages of decay (at least in terms of voter identification). Since 2005, identification with Mozambique's Frelimo has declined by almost forty percentage points, and by smaller though still considerable margins for the Botswana Democratic Party (-25 points), South Africa's African National Congress (ANC) (-23 points), Tanzania's Chama Cha Mapinduzi (CCM) (-20 points), and Namibia's SWAPO party (-15 points). ${ }^{3}$ Only in Uganda has the former guerrilla movement-come political party, Yoweri Museveni's National Resistance Movement (NRM), managed to recover much of the support it initially lost in this time period.

Support for the ruling party also varies over time in countries characterized by more competitive electoral outcomes, and in some instances, electoral turnover. Ruling parties (as of 2005) have met their virtual demise in Senegal (where PDS support dove 23 points) as well as Benin and Mali. On other hand, Zimbabwe's ZANU/PF managed to rebuild its support base which (along with systematic voter suppression and election violence and intimidation) enabled it to to retain power in the face of strong challenges from the opposition MDC. And in Ghana, which is the best example of an emerging, stable two-party system in Africa, support for the New Patriotic Party has fluctuated as it has settled into regularized competition with the National Democratic Congress.

The final piece of the puzzle has to do whether these longitudinal trends in aggregate support for ruling parties are linked to overtime changes in the type of performance related variables identified earlier. Because these variables do not always move in the same direction, and because other country-specific events clearly play important roles, a visual inspection of how all these trends move together does not always produce a clear conclusion. Perhaps the clearest illustration, however, of how overtime changes in the variables identified in our cross-sectional regression model match overtime changes in aggregate partisan identification can be seen in South Africa. Here, changes in voter identification with the ANC, since 1999, have varied over time in almost direct proportion to the percentage of South Africans who believe the country is headed in the right direction, and approve of the way the government is managing the economy. Thus, while ANC identifiers consistently had more positive views than other South Africans, they were not blind to economic conditions and political performance, and updated their evaluations of the party in a downward direction, especially after 2015, with mounting evidence of government corruption under President Jacob Zuma and its deleterious effects on the economy. 
[Figure 3 about here]

\section{Partisanship and Party Identification - Meaningful Concepts in Africa}

In this brief exploration of available Afrobarometer survey data, we conclude that both the concepts of partisanship and party identification are real and meaningful in Africa. While party identification is closely related to actual voting preferences, it is analytically distinct. Partisanship also exercises important influences on citizens propensity to become involved in a wide range of democratic politics, whether during or between elections. Our second contribution lies in terms of the nature of that impact. While we certainly have not tested a fully specified model of party identification, we have produced several nuggets of evidence which suggest that partisanship in Africa constitutes, at least for many voters, a "standing choice" rather than a fixed identity. That is, while voter support for ruling parties is clearly shaped by ethnicity (and other demographic background factors), it is not determined by them. Voter evaluations of the overall direction of the economy, national economic trends, and government responsibility for those trends, matter. Moreover, partisan identification acts as a cognitive lens that shapes, but does not determine people's evaluations of economics and politics, and thus does not prevent them from updating their evaluations when appropriate. Finally, aggregate levels of identification with the ruling party, or what other scholars have called "macropartisanship" (MacKuen, Erickson, \& Stimson, 1989) undergo important, and in some cases dramatic shifts over time. And at least in in some cases, macropartisanship moves in close correspondence to shifts in aggregate voter evaluations. All of this should be seen as evidence of an important, if little appreciated dimension of vertical accountability in Africa's multi-party regimes. 


\section{Notes}

${ }^{1}$ Afrobarometer surveys are based on interviews with cluster, stratified, area probability nationally representative samples of citizens 18 years and older. Samples are drawn using the most recent available census frames. Interviews are conducted in-person and in the language of the respondent's choice. Questionnaires are translated into all language groups comprising at least 5 per cent of the population. For more information, see www.afrobarometer.org. The question on partisanship was not asked in Swaziland where political parties are banned.

${ }^{2}$ In order to make the strongest test of evaluations unrelated to ethnicity, we do not use performance ratings of the President, members of parliament, or local councillors since those could conceivably be shaped by issues of co-ethnicity.

3 While we want to keep our focus on ruling parties in this chapter, it is important to note that one of the main challenges to democratic accountability is that declines in voter identification with ruling parties are often not matched by increases in support for opposition parties.

Rather, voters tend to shift into the non-aligned category, and are thus less likely to vote in subsequent election, often enabling the ruling party to win low turnout elections by significant margins. 


\section{References}

Bratton, Michael, \& Kimenyi, Mwangi. (2008). Voting in Kenya: Putting Ethnicity in Perspective. Journal of Eastern African Studies, 2(2), 272-289.

Bratton, Michael, Bhavnani, Ravi, \& Chen, Tse-Hsin. (2012). Voting Intentions in Africa: Ethnic, Economic or Partisan?. Commonwealth \& Comparative Politics, 50(1), 27-52. Basedau, Matthias, Erdmann, Gero, Lay, Jann, \& Stroh, Alexander. (2011). Ethnicity and Party Preference in sub-Saharan Africa. Democratization, 18(2), 462-489.

Burnell, Peter. (2002). Zambia's 2001 elections: The tyranny of small decisions, 'nondecisions' and 'not decisions'. Third World Quarterly, 23(6), 1103-1120.

Campbell, Angus, Miller, Warren, Converse, Philip, \& Stokes, Donald. (1960). The American Voter. Chicago: University of Chicago Press.

Daddieh, Cyril, \& Fair, Jo Ellen (Eds.). (2002). Ethnicity and Recent Democratic Experiments in Africa. New Brunswick: African Studies Association Press.

Dalton, Russell. (1984). Cognitive Mobilization and Partisan Dealignment in Advanced Industrial Democracies. Journal of Politics, 46(1), 264-284.

Englebert, Pierre, \& Dunn, Kevin. (2013). Inside African Politics. Boulder: Lynne Reinner Publishers.

Ferree, Karen. (2011). Framing the Race in South Africa: The Political Origins of Racial Census Election. Cambridge: Cambridge University Press.

Fiorina, Morris. (1981). Retrospective Voting in American National Elections. New Haven: Yale University Press.

Go, Julian. (2002). Modelling the States: Pre-Colonial Constitutions in Asia and Africa. Southeast Asian Studies, 39(4), 558-583.

Gunther, Richard, Jose Ramon Montero and Hans-Jürgen Puhle. (2006). Introduction: Intermediation, Information and Electoral Politics. In Richard Gunthe, Jose Ramon Montero, \& Hans-Jürgen Puhle (Eds.), Democracy, Intermediation and Voting On Four Continents. Oxford: Oxford University Press.

Hoffman, Barak, \& Long, James. (2013). Parties, Ethnicity and Voting in African Elections. Comparative Politics, 45(2), 127-146.

Horowitz, Donald. (1985). Ethnic Groups in Conflict. Berkeley: University of California Press.

Hydén, Göran. (2013). African Politics in Comparative Perspective. $2^{\text {nd }}$ Ed. Cambridge: Cambridge University Press. 
Ishiyama, John. (2012). Explaining ethnic bloc voting in Africa. Democratization, 19(4), 761 788.

Johnson, R.W., \& Schlemmer, Lawrence (Eds.). (1995). Launching Democracy in South Africa: The First Open Election, April 1994. New Haven: Yale University Press.

Key, Valdimer O. (1966). The Responsible Electorate. New York: Vintage Books.

Lever, Henry. (1972). The South African Voter. Cape Town: Juta.

Lindberg, Staffan. (2010). 'Its Our Time to "Chop"': Do Elections in Africa Feed NeoPatrimonialism rather than Counter-act It?. Democratization, 10(2), 121-140.

Lindberg, Staffan, \& Morrison, Minion K.C. (2008). Are African Voters Really Ethnic or Clientelistic? Survey Evidence From Ghana. Political Science Quarterly, 123(1), 95-122.

MacKuen, Michael B., Erikson, Robert S., \& Stimson, James A. (1989). Macropartisanship. American Political Science Review, 83(4), 1125-1142.

Mattes, Robert, Gouws, Amanda, \& Kotze, Hennie. (1995). The Emerging Party System in South Africa. Party Politics, 1(3), 379-393.

Mattes, Robert, \& Grouws, Amanda. (1995). Race, Ethnicity and Voting Behavior: Lessons From South Africa. In Timothy Sisk, \& Andrew Reynolds (Eds.), Elections and Conflict Management. Washington: United States Institute of Peace.

Mattes, Robert, \& Piombo, Jessica. (2001). Opposition Parties and the Voters in South Africa's General Election of 1999. Democratization, 8(3), 101-128.

Norris, Pippa, Mattes, Robert. (2013). Does Ethnicity Determine Support for the Governing Party? The Structural and Attitudinal Basis of Partisan Identification in 12 African Countries. Cambridge: John F. Kennedy School of Government, Harvard University Faculty Research Working Paper Series, FWPO3-00.

Ojo, Olatunde J.B. (1981). The Impact of Personality and Ethnicity on the Nigerian Elections of 1979. Africa Today, 28(1), 47-58.

Palmberg, Mai. (1999). National Identity and Democracy in Africa. Pretoria: Human Sciences Research Council Press.

Rabushka, Alvin, \& Shepsle, Kenneth. (1972). Politics in Plural Societies: A Theory of Political Instability. Columbus: Charles Merrill.

Reynolds, Andrew. (1994). The Results. In Andrew Reynolds (Ed.), Election '94 South Africa: The Campaigns, Results and Future Prospects. London: James Currey.

Salih, Mohamed, \& Markakis, John (Eds.). (1998). Ethnicity and the State in Eastern Africa. Uppsala: Scandanavian Institute of African Studies. 
Smith, Daniel. (2002). Consolidating Democracy: The Structural Underpinnings of Ghana's 2000 Elections. Journal of Modern African Studies, 40(4), 621-650.

Takougang, Joseph. (1996). The 1992 Multiparty Elections in Cameroon: Prospects for Democracy and Democratization. Journal of Asian and African Studies, 31(1-2), 52-65.

Van de Walle, Nicolas, \& Butler, Kimberly. (2007). Political Parties and Party Systems in Africa's Illiberal Democracies. Cambridge Review of International Affairs, 13(1), 14-28.

Verba, Sydney, \& Nie, Norman. (1972). Participation in America: Political Democracy and Social Equality. New York: Harper \& Row.

Young, Crawford. (1976). The Politics of Cultural Pluralism. Madison: University of Wisconsin Press. 